\title{
Socialist Transformation of Agriculture and Gender Relations: the Vietnamese Case
}

\author{
Christine Pelzer White
}

Although a great deal has been written both on the socialist transformation of agriculture and on women in socialist societies, there has been little overlap in the concerns of these two fields of inquiry. This is surprising given the crucial economic and social importance of gender relations and the sexual division of labour in the predominantly peasant agriculture of most pre-revolutionary societies, the continued importance of the 'family' sector in systems of collectivised agriculture, and the fact that women form the majority of the agricultural labour force in many socialist countries.

How do we account for the lack of integration of these two areas of analysis? In the Marxist-Leninist tradition there is some attempt to link the two, but 'relations of agricultural production' are considered to be primarily a class question. Although Lenin referred to women's subordination within the Russian peasant household and there is some analysis of a prerevolutionary 'patriarchal mode of production' [Stanis 1976:59], the question of relations of production within the patriarchal rural household has been far outweighed by the emphasis on the class status of the household as a unit relative to other households. ${ }^{2}$

Furthermore, whereas classes are defined in terms of exploitation and subordination within relations of production, women have been often thought of as a category marginal or extraneous to production and therefore production relations, engaged primarily in 'non-productive' domestic labour within the household [Molyneux 1981:178]. This derives partly from the fact that Marx focused on capitalist societies in which production had in large part been removed from the family workshop or farm and reconstituted in class terms in factories or as proletarianised agricultural labour for large landowners.

However, the division of workplace and the home, the

'I have benefitted particularly from discussions with Nguyen Huu Dong and Kate Young on the themes of this article. I am also grateful to Nguyen Huynh Chau and Judith Watson for their assistance at various stages of the research underlying this article, and to Jean Stubbs and Gordon White for comments on an earlier draft.

${ }^{2}$ In part this is because of the tendency to consider the household as a natural or 'seminatural' unit. Stanis [1976:59], defines the patriarchal mode of production as comprising "peasant households engaged in seminatural economy and weakly connected with the market'. For an excellent discussion of the issues involved in the concept 'household' which applies equally to a socialist context see Harris [1981]. spheres of production and reproduction, is not typical of pre-industrial, agrarian societies, and within recent years a growing literature has established the key role that kinship relations play in structuring production relations in peasant societies. Moreover, cultural phenomena often seen as 'superstructural', such as marriage customs and inheritance patterns, are important mechanisms by which access to and control of the means of production (primarily land and labour) are regulated and by which women are subordinated to men in peasant societies [Young 1978; Meillassoux 1981]. Since most socialist revolutions have taken place in agrarian societies characterised by a high percentage of family organisation of labour (whether on peasant smallholdings or tenant farms), the question of socialist reform in agriculture and transforming gender relations are therefore intricately connected, as this article attempts to establish in the case of Vietnam. ${ }^{3}$

As conventionally defined, socialist transformation of agriculture entails moving from small-scale subsistence and petty commodity production by peasant households to large-scale cooperatives, collectives and state farms involving a formally organised labour force. Small-scale production in family farms or workshops has been seen as 'backward': historically (precapitalist), economically (low productivity) and socially (low degree of division of labour and social cooperation), as well as politically suspect (a seedbed of capitalism).

There are striking parallels between this and the socialist programme for the emancipation of women. Just as small scale household production is associated with economic backwardness, isolated domestic labour within the confines of the household is held responsible for women's inferior social position. The proposed solution has been to involve women in social production outside the home and to socialise women's domestic work through the provision of crêches, canteens, etc. In this light, agricultural collectivisation has been seen as a major contribution to rural women's emancipation, providing both formal organisation and recognition of women's work in agricultural production and such social facilities as crêches and maternity clinics.

\footnotetext{
${ }^{3}$ For example, a land-owning peasant patriarch may well have different interests and at titudes with regard to collectivisation of his land from those of unpaid and landless 'family labour' (wife or wives and children), but this point is not made in the standard analytical literature on collectivisation.
} 
However, along with this fit between the standard socialist solution to the peasant problem on the one hand and the women's question on the other, there are contradictory aspects which appear most clearly in conceptions of the relationship between production and reproduction and policies toward 'the family". The 'socialist family' has been promoted as the appropriate social context for biological reproduction and the 'basic cell of society' because of what is generally seen as its 'natural', psychologically and economically irreplaceable role in the rearing of children and the care of old people. Moreover, it remains a widespread social assumption that the care of these people not yet or no longer engaged in productive labour is primarily women's work if social provisions outside the family are not available. In consequence, the family has occupied a highly ambiguous position: as a social unit, it is associated with women, notably the 'sacred task' of maternity; as an economic unit it has tended to be associated with 'individualism', the 'petty producer mentality' or capitalism.

In the concrete context of collectivised agriculture, it is the household or 'private' plot within the collective farm or cooperative which has been the primary embodiment of this ambiguous relationship between the spheres of production and reproduction. The continued resilience of this household or 'private' sector has long been considered problematic for socialist agriculture. It is equally problematic for the enhancement of women's socio-political role. Since women do the majority of work on the 'family plot' in addition to their 'non-productive' family tasks and 'social production' in the collective (socialist) sector, the concrete form that collective agriculture has taken has often contributed to women's work burdens [Croll 1979]. Not only do women have less time than men to devote to social, economic and political activities in the wider community, but their social and economic activities on behalf of the family are devoted to a sphere defined as ideologically inferior to the socialist sector.

In a number of socialist countries the strength of the household economic sector, and problems with productivity on state farms and collectives has led to a partial rethinking of the traditional socialist identification of large-scale agriculture with high productivity. In both China and Vietnam recent reforms have encouraged collective farms to subcontract agricultural production to peasant households. This innovation, called 'subcontracting of agricultural production' in Vietnam and the 'responsibility system' in China, sits uneasily with traditional thinking about socialist relations of production in agriculture and cannot adequately be analysed without reference to gender relations [cf Hazard].
This article takes Vietnam as a case study to illustrate the importance of sexual division of labour for understanding socialist institutional change, whether land reform, cooperativisation or the recent subcontracting system.

\section{From Family to Collective Agriculture: the Vietnamese Case}

My aim in this section is to summarise briefly the impact of the major structural changes from the precolonial system to the present on two basic and long-standing institutions, the village/cooperative and the farm family/household.

In pre-colonial Vietnam, villages were organised as collectivities of male household heads governed by councils of notables and endowed with legal, administrative, cultural and economic personalities, rights and responsibilities. The village's economic base was communal landholdings which included some fields earmarked to provide income for administrative, cultural, defence and social welfare costs, with the rest distributed on a regular basis among adult male villagers for usufruct for a period of a few years as 'subsistence shares' [Ngo Vinh Long 1973].

While some land ownership was communal, farming was not organised on a communal basis but by household, with some traditional forms of labour exchange. Although the distribution of communal land, as well as the inheritance of private land within the village, went to male villagers, agricultural production was not an exclusively male activity. A man could not farm without female labour. The very word for the verb 'to farm' in Vietnamese, câỳ câý, contains the words for 'plough' (cây) and 'transplant (rice seedlings)' (cây). These two verbs express a symmetry between the two essential steps in rice production which in traditional Vietnamese culture were the most strictly sex-typed: men plough, women transplant. This involved division of labour within a family unit, as well as neighbourhood groups of samesex workers.

Despite their crucial role in agricultural production, which extended to marketing activities outside the village, women were subordinated in both village and family. They were excluded from membership in the council of notables and from participation in village meetings, while within the household, few women had independent access toland. A widow's husband's land was generally inherited by a son or male relative, and any communal land allotment usually was taken back by the village. 


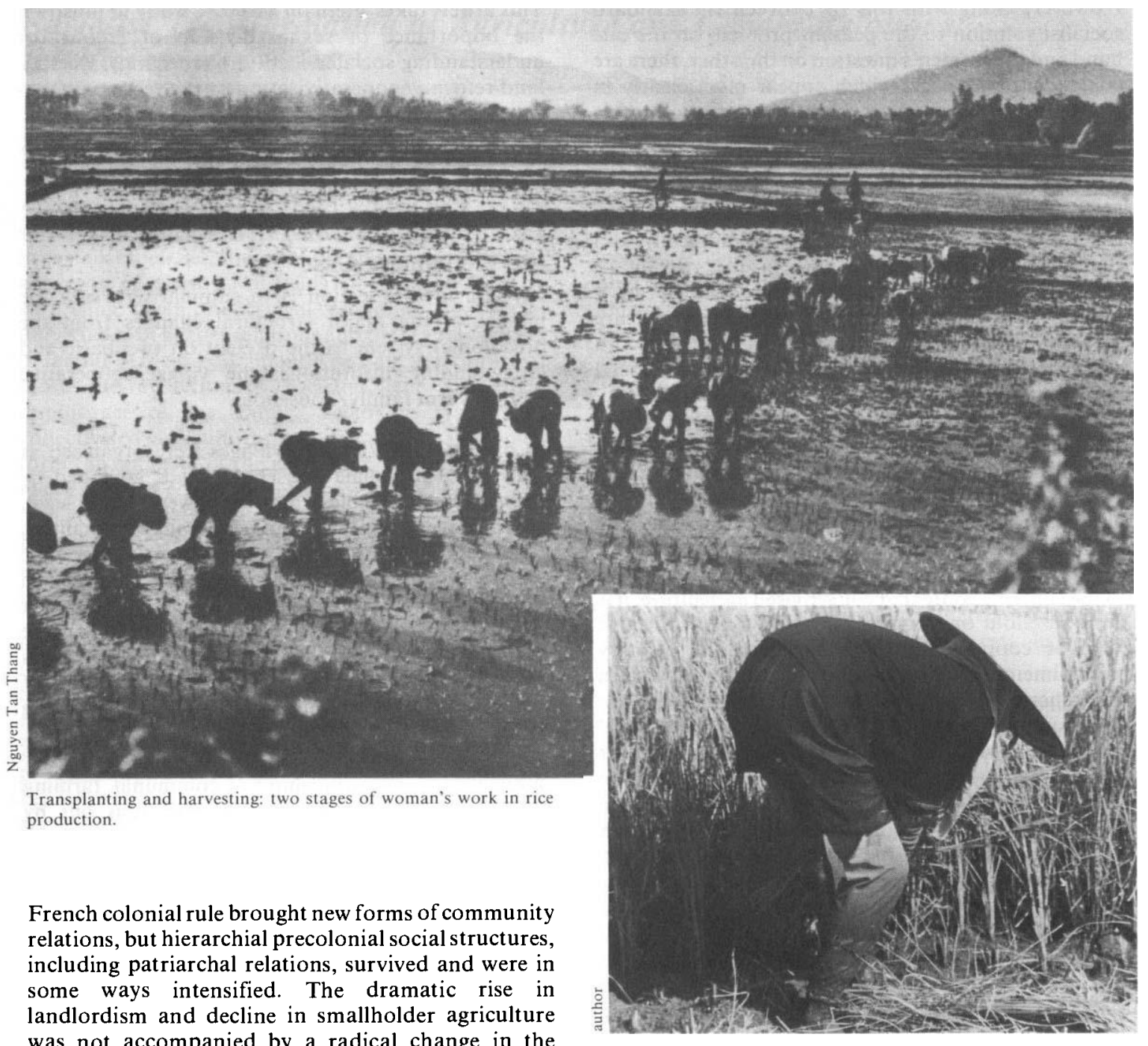
organisation of agricultural production (except on the relatively small plantation sector). The peasant smallholder, the tenant and the holder of a plot of communal land all generally farmed with household labour supplemented only at peak periods with mutual aid or some hired labour.

Following the expulsion of the French, the Vietnamese Communist Party completed a land reform which created relatively egalitarian distribution of land and other means of agricultural production. The land reform campaign (1953-56) eliminated ownership of land by non-tillers, abolished the vestiges of traditional communal land ownership and universalised a pattern of small peasant-owned holdings farmed by household labour. However, ownership was not explicitly patriarchal, and for the first time

women did receive land in their own name. Many women emerged as radical activists during the mass mobilisation against 'landlord exploitation' because of their additional suffering and resentment over patriarchal forms of exploitation. In a marked break from the traditional all-male pattern of village government, many women were elected to leadership posts during the land reform period [ $\mathrm{C}$. White 198 la].

Following the land reform, marriage and kinship remained the major form of labour recruitment in the now universalised 'family mode of production' (for discussion of this concept see Friedmann [1980]). It is probably not coincidental that new marriage legislation which outlawed polygamy, child marriage 
and parental control of their children's choice of marriage partner was introduced at about the same time that cooperativisation began the transformation from family to a larger, non-kin group as the main unit of agricultural production. Traditional forms of marriage which were disguised forms of labour recruitment had continued after land reform such as the practice of finding a strong young woman to work as unpaid family labour by marrying her to a son below working age. Not surprisingly, young women caught in such marriages often became activists in the campaign to form cooperatives, as membership in a newly-formed cooperative gave them independent access to employment [Vietnamese Studies 1966; Boudarel 1970]. Moreover, husbands tended to be more reluctant to join cooperatives than their wives, because of the threat to their 'independent' status as household head managing a family farm. In one village the difference was so marked that original household land was divided in two, with the women joining the cooperative and their husbands initially staying out [Pham Cuong and Nguyen Van Ba 1976:35].

As Vietnamese cooperatives developed, land ownership was collectivised and agricultural production on 95 per cent of each village's cultivated land was formally organised on the basis of work teams. All adult working members of households joined cooperatives, with men and women becoming cooperative members on an equal footing. The sexual division of labour within this larger unit of production generally continued the traditional pattern (eg male work teams for ploughing, female work teams transplanting), although during the wartime absence of many men, women carried out traditionally male tasks.

With the formation of cooperatives, women's agricultural work previously thought of as 'supplementary' or 'secondary', was measured, like that of men, in work points. According to Tran thi Hoan, a Woman's Union cadre who had been involved in the campaign to form cooperatives, "some husbands were very surprised when they saw how many work points their wives earned. Before they had thought that it was they who fed their wives, not their wives who fed them' [interview, Hanoi, September 1979]. Another advantage of cooperativisation was the possibility of giving pregnant women lighter work because the unit of production was larger. To quote Tran thi Hoan again:

if farming is done separately on a family basis then family members must do every step of production. In the family farming system, if it is time for transplanting or for harvest then all hands are needed, and the women must go to the fields, even if they are pregnant or have just given birth. We have documented cases of women with fallen uteruses from being forced to work too soon after childbirth.

While men had previously been the 'directors' of the family farm, the formation of cooperatives made it possible for women to be elected to management positions. During the war, when a large percentage of the men of working age were away at the front, there was an active policy of training and recruiting women for cooperative management posts (for a more extensive discussion see Werner [1981]).

The dependence of children and old people on the family was modified by new collective institutions. Crêches were set up in cooperatives, and a uniquely Vietnamese institution, the old people's orchard, with a shaded rest place or house, provided a social meeting place and profit able economic activities for cooperative members who no longer had the strength to work in the rice fields. In a cooperative visited by the author in 1979 , the old people's team even played a role in making marriage a cooperative rather than just a family affair: their garden provided flowers for weddings and furniture for new households was made by their carpentry workshop.

However, the system of collective (in Vietnam usually termed cooperative) agriculture did not entirely supplant the role of the household in the organisation of production, let alone in the sphere of 'reproduction'. Although agricultural land was collectivised, each household retained its house and garden and also had usufruct of a small portion of the cooperative's land for use as a 'family plot'. As the household remained the residential unit, the conditions for a home-based 'family economy' remained within the cooperative.

The coexistence of family and collective organisation of agricultural production typical of most socialist countries is a problematic question discussed elsewhere in this Bulletin [Selden; Dong]. In the case of Vietnam, the system could be characterised as a symbiosis, as the family economy has not been neatly contained within the confines of the house and yard and the family plot. To a remarkable extent formally collectively organised steps in the production process on cooperative land were dependent on inputs from the household/family sector unless modern inputs were available from the state. For example, household pig manure provided the major source of fertilizer for the collective fields on an obligatory delivery basis, and seed storage and the care of cooperative draft animals were commonly subcontracted to cooperative households. Some cooperatives found it more economic to rent draft animals from private owners than pay the cost of machines from the district tractor station. The cooperative and family economic sectors were frequently in competition: for work time, for pig 
manure, and even for the harvest on cooperative fields, (eg mothers harvesting for the cooperative reportedly would drop grains for their children to glean for the household or for their private ducks to eat).

One of the most paradoxical aspects of Vietnamese socialist rural development is the extent to which the development of the cooperative economy has been accompanied by an expansion in the infrastructure of the family economy. Whereas capitalist development erodes subsistence production and family based petty commodity production, Vietnam's form of socialist development has had an opposite effect. The cooperative system ensures that the house and access to a small plot of land, the basis of small scale peasant production, cannot be lost through bankruptcy. A peasant house is not just a place of residence but a place of production including pigs and chickens in the courtyard, home handicraft manufacture in the slack season, etc. Much of this work is considered 'women's work' due to its compatibility with women's other household chores. Before land reform and cooperativisation, only a handful of landlord and rich peasant families in each village had tile-roofed brick houses, brick courtyards to dry their rice and solid piggeries. Now a large percentage, in many areas the overwhelming majority, of cooperative members enjoy such quarters built in the 1960s and 1970s with bricks, tiles and lime produced by cooperative workshops. In other words, the cooperative system has helped to build up the infrastructure of the family economy.

Another development of the 1960s and 1970s was that collective agriculture became and remained a socioeconomic sector with a primarily female labour force (at least 60 per cent and often much higher, depending on the region and the intensity of wartime mobilisation). Because of what are seen as women's 'family responsibilities' for the care of the young and old, far more men than women have been recruited from the villages for state sector jobs and duties, whether in the army, in urban industry, transportation or administration. The combination of cooperative agriculture with the family social system facilitated military mobilisation since soldiers could rest assured that the cooperative would guarantee their family's economic needs and that their wives would take care of both their children and their husbands' aged parents, an aspect of traditional patriarchal culture strongly encouraged by the socialist government.

In sum, a number of economic and social aspects of 'the family' were strengthened in symbiosis with the collective agricultural system. New aspects of sexual division of labour began to emerge, with more men in the state sector and more women in the cooperative sector.

\section{Subcontracting: a New Sexual Division of Labour?}

In the orthodox Marxist-Leninist conception the 'peasant question', which in Vietnam in particular largely overlaps with the 'woman question', is to be resolved by the eventual establishment of large agroindustrial complexes and the merging of the peasantry into the wage-earning working class. Towards the end of the war there was a strong policy push in this direction in order to move beyond the wartime situation of relatively limited commoditisation, semiautarkic cooperatives, and a strong family economy sector (for a fuller discussion of shifts in development thinking, see White [1982]).

In a speech at an important national conference on agricultural policy in August 1974 the Party SecretaryGeneral sketched out a blueprint for moving as quickly as possible towards 'large-scale socialist agriculture' which was presented as a political as well as an economic necessity, as 'small production by itself begets capitalism daily and hourly' [Le Duan 1975:55]. The clear implication of the speech was that the autonomous role of the collective and family economies should be reduced, and the state role in planning and organising production increased.

In a postwar context exacerbated by the conflict with China this policy did not succeed and food supply problems reached crisis proportions. In 1979, at the Sixth Plenum meeting of the Party leadership, a dramatic new policy direction affirmed the key importance of small-scale production at Vietnam's present stage of economic development and opened the door for the 'family economy' to make use of economic resources, including land, not being utilised by the cooperative [Nguyen Huu Dong 1981; White 1981b]. This was followed in late 1980 and early 1981 by government advocacy of subcontracting cooperative land to cooperative members for the final stages of the production process, a de facto encouragement of household organisation of agriculture going far beyond the previous symbiosis of cooperative agriculture and the family economy.

Because of the increasing sociological differentiation within northern Vietnamese villages which has begun to be documented in household surveys within the last few years, [Duc Uy and Vu Van Thao 1980; Houtart and Lemercinier 1981] along with diversity between villages and regions, the range of social relations involved in the new subcontracting system is quite wide. Furthermore, ambiguities in policy and practice over whether the subcontracting is to individuals or to 
households makes it particularly difficult to clarify the sociological implications.

In part, the analytical confusion stems from the fact that a rural agricultural producers' cooperative in Vietnam is an economic unit of production based on place of residence (a hamlet or village made up of household units) in a country where social relations are becoming increasingly complex (through increased mobility and occupational differentiation) but where kinship ties are still very strong indeed, with economic as well as social aspects. Therefore, each 'individual'. cooperative member is simultaneously part of several wider social entities, including the cooperative, a kin network ('family' consisting of relatives whether resident in the village or not) and a unit of residence ('household', usually a subset of the wider family group).

To simplify the picture it is possible to hypothesize that two major and very different patterns would emerge depending on the pre-existing mix of state and family sector inputs. In the first type, a high level of state-supplied inputs would enable the cooperative to continue to organise a number of steps of the production process effectively. This is the pattern which the government would prefer to see generalised since it maximises control by the socialist sector. It is probably no coincidence that the model for the subcontracting system is the Haiphong area (near the major port) which has an exceptionally high level of mechanisation and other state-supplied inputs. However, in the more typical situation of low state inputs and heavy cooperative dependence on family sector contributions, it is likely that the new system entails a return to household organisation of production for all steps of the labour process. The implications for gender relations in the two patterns are quite different.

The first type received most publicity as it was the officially encouraged model. The government policy directive on subcontracting makes no mention of households, only to 'giving groups of workers and individual workers contracts for product quotas'. The directive stresses that the new method must not allow 'any individual cooperative member to take charge of the whole process of production - from ploughing to harvesting'. Instead, the cooperative and production teams must be 'directly responsible for carefully organising labour in specialised teams and groups to perform important operations requiring technical expertise and the use of collective technical and material facilities', including land preparation (ploughing and harrowing), water control (irrigation and drainage), work related to seeds and seedlings, management and distribution of fertiliser, prevention and control of diseases and harmful insects, and crop protection. On the other hand, 'operations requiring manual labour that can be satisfactorily performed by individual workers' are not to be directly managed by the cooperative but contracted out to 'groups of workers or individual workers'.

In both Vietnam's traditional and present existing sexual division of labour, those tasks defined as 'important' and 'technical' which are to be directly organised by the cooperative sector include all the steps done exclusively or primarily by men (ploughing, irrigation work, uprooting seedlings ...) while the implicitly less 'important' tasks suitable for an individual labour process and to be subcontracted are done primarily by women (transplanting, weeding, harvesting).

Articles on a village considered exemplary for implementation of the new system in both the party newspaper, Nhan Dan, 15 December 1980, and the Women's Union Newspaper, Phu Nu Viet Nam, 3, 17 March 1981, indicate a clear sexual division of labour between collective work by men and subcontracted work by women. Son Cong cooperative, Ung Hoa district, Ha Son Binh province was, like cooperatives in the Haiphong area, among the pioneers of the new system, and enjoyed a relatively high level of mechanisation. The 300 men in nine ploughing teams with seven tractors and 260 draft animals worked directly for the cooperative and were not party to the contracts, while transplanting, caring for rice (including fertilising) and harvesting were contracted out to the cooperative's female workforce. Not surprisingly, there had been struggles between the women subcontractees and the ploughmen over the allocation of inputs and payment. The women had demanded that since the men had not done a good job of ploughing, they should have extra fertiliser and a greater share of the final product.

While there are obvious negative implications for women in a system which associates collective work and technical expertise with men's work, the subcontracting system does highlight women's manual labour input as crucial to the success of the harvest and may strengthen women's collective bargaining position.

On the other hand, in the second type of contracting where the entire labour process is subcontracted to a household head to mobilise and deploy household and family labour, the result could be a strengthening of traditional patriarchal authority. However, in rural Vietnam there are many female household heads, both windows and women with husbands virtually permanently absent in the army, administration or industry. Even where a man is present, women sometimes control the disposition as well as the 
generation of the family economy; traditionally women are the family accountants. Where women do control the family economy in all senses, the present relaxation of administrative controls on women's income-generating activities, including marketing (as women are traditionally the rural market sellers in Vietnam) could have a partially beneficial effect for women. One aspect of the new system is to allow greater freedom for agricultural producers (the overwhelming majority of whom are women) from interference from administrators (the overwhelming majority of whom are men).

Whereas the intent of most previous structural reorganisations in agriculture had been to increase the formal organisation of the work force, to specify universal norms for production and distribution and to transform the social structure, the new policy is an attempt to mobilise existing informal social ties in order to increase productivity. It is left up to the existing social relations between individuals within households and families which have received land on subcontract to determine what the distribution of work and product will be. Government policy is only concerned with the contractual relationship between the cooperative and the contractee (obligation to deliver a certain quota of production). Discussions of the new system make it clear that individual subcontractees are expected to mobilise labour within the household (eg, children and old people) as well as family members not resident within the household (eg, husbands or other relatives working in urban jobs in industry or the civil service who could ask for leave to participate in family agricultural production) [Nguyen Huy 1980]. Unlike the cooperative workpoint system, which quantified the labour inputs of household members on cooperative fields separately, the new system could once again create undifferentiated 'family labour' without any external norm as to how the workload or income should be distributed within the household or family. As we have seen, one of the advantages for women of cooperativisation was that the workload could be shared more widely; unlike in the family farm system, pregnant women did not have to do heavy labour such as transplanting. The new system appears to be increasing productivity by intensifying women's workload with negative results for women's health, as well as making it more difficult to compare the relative economic and labour contributions made by men and women.

Productivity is up because women are given the financial incentives to work harder, but meanwhile women's burdens in the sphere of reproduction have also increased. The new system has reportedly had a negative impact on the collective child care system as crêche workers find it more lucrative to take up a contract for agricultural labour and crêches have difficulty getting staff. The population implications of a family farming system (especially in wet rice agriculture) where there are economic advantages in having many children have been well documented [B. White 1976]. If population growth is not checked, it will quickly negate any improvements in productivity.

In sum, the new system seems to accentuate already existing tendencies toward a new form of women's subordination, with men concentrated in the state and cooperative (socialist) sectors and women's labour power mobilised as 'subcontracted' manual labour on an individual or household basis. Women's 'privatised' work within the family, the sphere of reproduction, has spilled over into the de-socialising of their work in agricultural production.

\section{Conclusion}

The present policy to harness the economic potential of small-scale production is a major reversal of orthodox socialist thinking about 'economies of scale' in agriculture, and as such seems a very positive development. However, a development policy which achieves short term economic results by overburdening the female labour force and taking advantage of the tendency to intensive 'selfexploitation' in household agriculture can hardly be viable as a long term socialist development policy. At the present time, the subcontracting system is still under debate, with the orthodox seeing it as a temporary tactical retreat in the forward march toward 'large-scale socialist agriculture'. However, debates over scale are largely beside the point unless there is creative thinking by socialists in Vietnam and elsewhere about a new sexual division of labour and new means of coordinating the spheres of production and reproduction so that men and women can function effectively as workers and parents and as individual and social beings.

\section{References}

Boudarel, George, 1970, 'L'evolution du statut de la femme dans la Republique Democratique du Vietnam', Tiers Monde, (Paris), vol 11 nos 42, 43

Croll, Elisabeth, 1979, 'Socialist development experience: women in rural production and reproduction in the Soviet Union, China, Cuba and Tanzania', Discussion Paper 143, IDS, Sussex

Duc Uy and Vu Van Thao, 1980, Nhan Dan, 24 June 1980; excerpts available in English translation in Vietnam Courier, (Hanoi) 8, pp 12-13 
Friedmann, Harriet, 1980, 'Household production and the national economy: concepts for the analysis of agrarian formations', Journal of Peasant Studies, vol 7 no 2, pp 158-81

Harris, Olivia, 1981, 'Households as natural units' in $\mathbf{K}$. Young, C. Wolkowitz and R. McCullagh (eds), Of Marriage and the Market, CSE Books, London

Houtart, Francois and Genevieve Lemercinier, 1981, Sociologie d' une Commune Vietnamienne, CRSR, Universite Catholique de Louvain, Louvain-la-Neuve

Le Duan, 1975, Towards a Large-Scale Socialist Agriculture, FLPH, Hanoi

Lenin, V., 1966, The Emancipation of Women, International Publishers, New York

Mai thi Tu and Le Thi Nham Tuyet, 1978, Women in Vietnam, FLPH, Hanoi

Meillassoux, Claude, 1981, Maidens, Meal and Money: Capitalism and the Domestic Community, Cambridge University Press

Molyneux, Maxine, 1981, 'Women in socialist societies: problems of theory and practice' in K. Young et al (eds), Of Marriage and the Market, CSE Books, London

Ngo Vinh Long, 1973, Before the Revolution: the Vietnamese Peasants under the French, MIT Press, Cambridge, Mass

Nguyen Huu Dong, 1980, 'Agriculture collective, agriculture familiale, économie socialiste: quelques hypothèses', Vietnam, Paris, no 1, pp 6-24

- 1981, '6e plenum: adaptions conjoncturelles ou réformes durables? Essai sur la politique économique du socialisme', Vietnam, Paris, no 2, pp 41-60

Nguyen Huy, 1980, 'Ve cac hinh thuc khoan trong hop tac xa trong lua'. (On forms of subcontraction within ricegrowing cooperatives), Nghien Cuu Kinh Te (Economic Research Journal), Hanoi, no 118, pp 9-23
Nguyen Xuan Lai, 1967, 'The family economy of cooperative farmers', Vietnamese Studies, Hanoi, no 13, pp 107-28

Pham Cuong and Nguyen Van Ba, 1976, Revolution in the Village: Nam Hong 1945-1975, FLPH, Hanoi

Stanis, Vladimir, 1976, The Socialist Transformation of Agriculture, Progress Publishers, Moscow

Vietnamese Communist Party Central Committee, 1981. Directive 100-CTTU on contractual work, 13 January. Full text in English translation in Summary of World Broadcasts (BBC) FE/W 1120/A/22, 11 February

Vietnamese Studies, 1966, special issue on Vietnamese women, no 10

Vu Can, 1981, 'Linking co-op members to their produce', Vietnam Courier, vol 17 no 2

Werner, Jayne, 1981, 'Women, socialism and the economy of wartime North Vietnam, 1960-1975', Studies in Comparative Communism, vol 14 nos 2,3

White, Benjamin, 1976, 'Population, employment and involution in rural Java', Development and Change 7 , pp 267-90

White, Christine, 1981a, Agrarian Reform and National Liberation in the Vietnamese Revolution: 1920-1957, University Microfilms, Ann Arbor

- 1981b, 'Interview with Nguyen Huu Tho, Agricultural Editor of Nhan Dan', Journal of Contemporary Asia, vol 11 no 1, pp 127-30

-1982, 'Debates in Vietnamese development policy', Discussion Paper 171, IDS, Sussex

Young, Kate, 1978, 'Modes of appropriation and the sexual division of labour: a case study from Oaxaca, Mexico', in A. Kuhn and A. M. Wolpe (eds), Feminism and Materialism: Women and Modes of Production, Routledge and Kegan Paul, London 